\title{
Karakter Diplomasi Publik Indonesia terhadap Malaysia
}

\author{
Iva Rachmawati \\ International Relations Department \\ Faculty of Social and Political Science \\ UPN Veteran Yogyakarta \\ Jalan SWK 104, Sleman, Yogyakarta 55283, Indonesia \\ iva.rachmawati@upnyk.ac.id \\ Submitted: 21 Juli 2017, Accepted: 16 September 2017
}

\begin{abstract}
Public diplomacy, as an effort to maintain the system of inter-state relations and also its existence in the international environment, refers to the communicative activities of the state as well as the domestic public to the public outside the state. Public diplomacy then becomes a supportive tool for maintaining inter-state relations and avoiding conflicts arising between countries. However, in Indonesia-Malaysia relations, the practice of public diplomacy tends to lead to negative actions in influencing relations. This article shows that negative Indonesian public diplomacy towards Malaysia has been influenced by distinctive characters, reactive and inferior. Those characters were formed by historical frame on collective memory which collide Malaysian NEP impact. As a result, public diplomacy does not exist as a bridge to maintain relationships positively but rather tends to be practised through negative communication forms. This article is a result of qualitative research methods based on interviews and literature studies.
\end{abstract}

Keywords: Character of public diplomacy, history, state policy, reactive, inferior, negative communications

\begin{abstract}
Abstrak
Diplomasi publik, sebagai upaya untuk memelihara sistem relasi antar negara dan juga keberadaannya dalam lingkungan internasional yang merujuk pada aktfitas komunikatif publik domestik suatu negara terhadap publik di luar negara. Diplomasi publik kemudian menjadi alat yang suportif untuk menjaga relasi antar negara dan menghindarkan negara dari konflik akibat persoalan yang muncul antar negara. Namun, pada relasi Indonesia-Malaysia, praktik diplomasi publik cenderung mengarah pada tindakan-tindakan yang negatif dalam memengaruhi relasi. Artikel ini menunjukkan bahwa praktik-praktik diplomasi publik Indonesia terhadap Malaysia yang negatif tersebut dipengaruhi oleh karakter yang khas, yaitu karakter reaktif dan inferior. Karakter tersebut terbentuk oleh bingkai sejarah pada memori kolektif yang bertemu dengan dampak NEP Malaysia. Akibatnya, diplomasi publik tidak hadir sebagai jembatan untuk memelihara relasi secara positif melainkan cenderung dipraktikkan melalui bentuk-bentuk komunikasi yang negatif. Artikel ini merupakan hasil riset yang dilakukan dengan metode kualitatif berdasar pada wawancara dan studi literatur.

Kata Kunci: Karakter diplomasi publik, sejarah, kebijakan negara, reaktif, inferior, komunikasi negatif.
\end{abstract}

\section{PENDAHULUAN}

Diplomasi publik merupakan sebuah upaya untuk memelihara kesepahaman dan relasi keberadaan diri dalam pergaulan antar negara (Rachmawati, 2017). Diplomasi publik juga menjadi upaya komunikatif yang positif dalam menengahi sejumlah isu antar negara. Diplomasi lahir dari rahim rasionalis yang percaya pada pandangan akan pentingnya masyarakat internasional dalam menjamin tercapainya kepentingan bersama masing-masing negara dan terciptanya perdamaian dunia. Dengan demikian, proyek kaum rasionalis menekankan pentingnya dialog dalam pergaulan internasional (Jackson\&Sorensen, 1999:190). Sementara perspektif identitas menyadari bahwa diplomasi merupakan bagian dari gerak komunikasi sistem yang alamiah dalam memelihara identitas dirinya (Luhmann, 1995).

Diplomasi publik kemudian hadir sebagai upaya yang tidak saja dilakukan oleh negara tetapi juga aktor non negara di dalam negeri atau dimensi domestik untuk 
menjaga relasi dan menjalin kesepahaman. Unsur kesadaran sebagai bagian dari sistem menghubungkan subsistem untuk bergerak dalam sistem dan menjadikannya bagian dari motivasi. Upaya subsistem dalam menduplikasi upaya komunikatif sistem mengantarkanya menjadi agen diplomasi yang juga mengupayakan kesepahaman dalam menjalin relasi. Tidak jarang mereka mampu mandiri bergerak di luar negara (Luhmann, 1995). Diplomasi publik adalah tentang membangun hubungan; memahami kebutuhan negara lain, budaya dan masyarakat; mengomunikasikan sudut pandang kita; memperbaiki kesalahan persepsi; mencari isu di mana kita bisa membangun kerja sama. Perbedaan antara diplomasi publik dan tradisional adalah bahwa diplomasi publik melibatkan kelompok orang yang jauh lebih luas di kedua belah pihak (Leonard, Stead, dan Sweming, 2002:8-9). Studi yang dilakukan atas diplomasi publik menunjukkan bahwa negara maupun dimensi domestik mampu mengamalkan sejumlah tindakan yang suportif atas penyelesaian persoalan dan pemeliharaan relasi. Diplomasi publik oleh negara bersama dengan media misalnya, mampu menciptakan wacana baru mengenai bahaya terorisme (Entman, 2003) dan atau memengaruhi perspektif publik secara umum mengenai peristiwa tertentu (Gilboa, 2002; Ammon, 2001).

Kemampuan aktor non negara sebagai agen diplomasi publik untuk memengaruhi relasi dan mengenalkan norma baru diselenggarakan melalui jejaring yang mereka miliki dengan aktor non negara di luar negara. Melalui jejaring yang dimiliki oleh sejumlah NGO, Protorious (2011) mengklaim bahwa Global Witness1 dan Eurodad2 berhasil meyakinkan sejumlah negara untuk menyepakati the Kimberley Process Sertification Scheme atas perdagangan berlian untuk melindungi pekerja tambang yang berkerja di perusahaan-perusahaan tambang berlian. Demikian juga Sharp (2001), menunjukkan bahwa kerja sama antar warga melalui skema kota kembar (sister city) mampu menumbuhkan dan mengembangkan relasi yang positif antar warga antar negara. Sementara Kupinska (2010) mengklaim bahwa kelompok bisnis mampu menjadi jembatan bagi relasi antar negara yang tidak saling mengakui seperti Tiongkok dan Taiwan. Dan tidak jauh berbeda, Malik (2012) menemukan peran penting Aman Ki Asha (House for Peace) yang dibentuk oleh media massa The Jang Group dan the Times of India dalam menjembatani hubungan India dan Pakistan.

Namun demikian, pada praktik-praktik diplomasi publik Indonesia terhadap Malaysia justru ditemukan sejumlah tindakan negatif dalam memengaruhi relasi bilateral. Diplomasi publik seakan gagal menghadirkan sikapsikap yang positif dalam memelihara relasi antar negara. Pada sejumlah isu Indonesia-Malaysia ditemukan bahwa aktor domestik non negara (dimensi domestik) memilih tindakan negatif atas hal tersebut. Pada isu perbatasan, budaya dan juga tenaga kerja migran, sekelompok aktor domestik non negara memilih demonstrasi, ancaman sweeping hingga netwar dibanding tindakan-tindakan kooperatif lainnya seperti kerja sama budaya, kajian perbatasan dan atau kerja sama perlindungan tenaga kerja migran. Meski ada pula mereka yang menyelenggarakan kerja sama budaya3 dan akademik4, namun hal tersebut masih sangat terbatas dan belum memberikan dampak positif secara menyeluruh. Sementara negara cenderung sangat lunak5.

Pada sejumlah isu bilateral yang sering hadir mewarnai relasi Indonesia-Malaysia, terlihat baik negara maupun dimensi domestik cenderung mengambil sikap yang reaktif dan inferior terhadap Malaysia. Sikap reaktif ditunjukkan dengan tindakan yang hanya muncul ketika Malaysia mengambil sikap atau kebijakan tertentu. Misalnya, sikap negatif berupa demonstrasi dan ancaman atau dialog mengenai isu terkait dilakukan setelah klaim perbatasan maupun klaim budaya terjadi. Sedangkan inferior ditunjukkan dengan sikap-sikap yang cenderung curiga dan kekhawatiran yang berlebihan. Misalnya, ujaran 'Indon' menjadi ujaran yang dianggap merendahkan harga diri bangsa. Adapun 'klaim' pada budaya diartikan sebagai mencuri budaya. Hal tersebut kemudian mudah memicu kemarahan dan sentimen negatif di dalam negeri meskipun belum memahami makna sesungguhnya dari ujaran 'Indon' maupun 'klaim'.

Artikel ini hendak menunjukkan bahwa karakter yang mewarnai diplomasi publik Indonesia terhadap Malaysia tersebut bukanlah karakter yang sekedar muncul begitu saja dalam setiap upaya komunikatif negara dan aktor domestik non negara. Karakter tersebut terkonstruksi oleh perjalanan sejarah kedua negara dan kebijakan negara yang 
secara sistematis terpatri melalui sejumlah instrumen pengantar memori.

Artikel ini merupakan hasil riset yang didasarkan atas pendekatan kualitatif melalui metode wawancara dan studi literatur yang dibagi dalam dua bagian. Bagian pertama menjelaskan mengenai karakter yang muncul dalam diplomasi publik Indonesia yaitu reaktif dan inferior. Pendekatan psikologis digunakan untuk memahami bagaimana kedua karakter ini hadir dalam interaksi kedua negara. Sedangkan bagian kedua merupakan penjelasan mengenai faktor yang membentuk karakter diplomasi publik, yaitu sejarah dan perubahan kebijakan politik dan ekonomi Malaysia. Sementara itu, diplomasi publik Indonesia yang masih menjadi bagian dari kontestasi elit menjadi faktor lain yang semakin menguatkan karakter diplomasi publik Indonesia.

\section{PEMBAHASAN}

KARAKTER DIPLOMASI PUBLIK INDONESIA: REAKTIF DAN INFERIOR

Sikap reaktif sesungguhnya merujuk pada sikap seseorang yang gagal membuat pilihan respon di kala mendapat stimulus. Orang yang reaktif cenderung bertindak secara spontan, tidak berdasar pada nilai-nilai yang dianut dan membiarkan diri dikendalikan oleh lingkungan sosial bukan oleh diri sendiri (Covey, 1997:61). Karakter reaktif lebih menfokuskan pada keadaan yang tidak bisa dikendalikan oleh diri sendiri. Hal tersebut berakibat pada perasaan menjadi korban, sikap menyalahkan orang lain dan bahasa yang reaktif. Covey menengarai bahwa karakter reaktif dicirikan sebagai mudah tersinggung, cenderung menyalahkan orang lain, cepat marah, mudah mengeluh, bersikap menunggu dan tidak mau melakukan perubahan (Covey, 1997:84).

Bagi McGeer, perilaku reaktif tidak terkait dengan hal yang baik atau buruk tetapi perilaku reaktif adalah perilaku yang merupakan respon atas apa yang orang lain lakukan terhadap diri. Ia bukan merupakan perilaku yang diinisiasi oleh individu terhadap individu yang lain. Oleh karenanya, respon hanya ditunjukkan kepada mereka yang dirasa bertanggung jawab atas sikap yang dimunculkan (McGeer, 2010). Demikian juga Scanlon yang merujuk pada reaksi atas hubungan antar individu atau kelompok yang terganggu tanpa mengacu pada sikap yang positif atau negatif atas hal tersebut (Scanlon, 2008). Karakter reaktif dengan demikian dapat disimpulkan merupakan sikap yang ditujukan sebagai respon terhadap tindakan seseorang atau kelompok yang tidak dikehendaki dan tidak jarang ditujukan untuk mengubah relasi yang dimiliki.

Karakter reaktif dalam diplomasi publik Indonesia terhadap Malaysia ditemukan ketika upaya-upaya yang dilakukan oleh negara dan atau dimensi domestik dalam rangka memelihara keberadaan dirinya dan memengaruhi relasi merujuk pada sejumlah aktifitas yang seakan tidak memiliki perencanaan yang matang. Ia muncul sebagai bagian dari respon sikap dan atau kebijakan yang diambil oleh Malaysia. Ia bukan merupakan aktifitas yang reguler dan berkesinambungan dan cenderung sarat dengan emosi. Sejumlah dimensi domestik yang secara reguler memelihara relasi secara mandiri tentu tidak memiliki karakter semacam ini, namun sayangnya gerak mereka cenderung terabaikan baik oleh negara maupun publik domestik.

Karakter reaktif ditemukan dalam praktik diplomasi Indonesia baik oleh negara maupun dimensi domestik. Pada masa orde lama, di mana diplomasi didominasi oleh elit, praktik diplomasi yang reaktif ditemukan dalam diplomasi konfrontatif Soekarno melalui sejumlah monolog yang emosional seperti pidato 'Ganyang Malaysia' tahun 1963, 'Vivere Pericoloso' di tahun 1964 dan pidato Dwikora di tahun 1964. Monolog tersebut merupakan sikap reaktif elit atas sikap Malaysia yang dinilai membahayakan Indonesia karena kedekatannya dengan Inggris. Label sebagai antek imperialis dilekatkan kepada Malaysia sebagai bentuk ketidakmampuan merubah pilihan kebijakan Malaysia. Demikian juga penempatan diri sebagai korban dalam pidato tersebut menunjukkan bahwa pidato Soekarno merupakan sikap yang reaktif. "... Serukan serukan keseluruh pelosok negeri bahwa kita akan bersatu untuk melawan kehinaan ini kita akan membalas perlakuan ini dan kita tunjukkan bahwa kita masih memiliki gigi yang kuat dan kita juga masih memiliki martabat...." (Seruan Soekarno: 'Hajar Cecunguk Malayan, Ganyang Malaysia!'). Monolog menjadi upaya untuk menularkan sikap reaktif kepada publik yang kemudian tergerak melalui Dwikora.

Sikap reaktif sedikit banyak berkurang dengan dilaluinya low profile politics pada masa Tun Razak dan 
Orde Baru di masa awal Soeharto memerintah. Keduanya bersama-sama menjadi inisiator bagi lahinrya ZOPFAN (Zone of Peace, Freedom and Neutrality) dan TAC (Treaty of Amity and Cooperation), dekolonisasi Brunei, normalisasi hubungan dengan Tiongkok dan Vietnam sebagai partner ASEAN. Kembali dijalinnya hubungan Indonesia-Malaysia melalui politisasi 'Serumpun' menyumbangkan stabilitas hubungan kedua negara. Malaysia cenderung menempatkan dirinya secara subordinan terhadap Indonesia dengan rajin mengonsultasikan semua kebijakannya kepada Indonesia.

Sikap reaktif elit kembali ditunjukkan pada masa Mahathir melalui persaingannya dengan Soeharto. Mahathir mulai terlihat meninggalkan mitos 'Serumpun' dengan menjadi lebih lugas kepada Inggris dan berperan aktif di dalam PBB dan GNB. Ia pun menentang Soeharto dengan ide FPDA-nya (Five Power Deffence Arrangement), sementara Soeharto bersikap reaktif dengan ide EAEGnya (the East Asian Economic Group). Dalam berbagai kesempatan, diplomasi sebagai 'abang' masih dinampakkan oleh Indonesia untuk menekan sikap Malaysia yang dianggap mulai meninggalkan sikap konsultatifnya di masa Husein Onn.

Pada masa reformasi, sikap reaktif terhadap Malaysia tidak saja ditunjukkan negara tetapi juga publik domestik yang semakin mudah mendapatkan akses informasi dan komunikasi. Munculnya kontroversi atas klaim wilayah dan budaya Indonesia oleh Malaysia menunjukkan bahwa negara belum memiliki desain yang jelas atas pengelolaan wilayah perbatasan dan juga pemeliharaan budaya nasional. Negara cenderung bersikap reaktif ketika muncul 'klaim' oleh Malaysia. Indonesia baru mengeluarkan kebijakan yang seolah-olah berpihak pada pengembangan budaya daerah atau nasional. Sementara itu sikap reaktif publik juga mudah terpicu oleh berita mengenai klaim wilayah serta budaya dan isu mengenai penyiksaan terhadap tenaga kerja migran Indonesia. Sebaliknya upaya untuk memelihara identitas geografis dan budaya tidak dilakukan secara reguler. Jikapun ada dimensi domestik yang melakukannya, maka skopnya sangat terbatas dan jarang didiseminasikan secara luas.

Pada isu perbatasan misalnya, klaim Malaysia atas Ambalat sesungguhnya sudah dapat ditengarai semenjak persoalan Sipadan Ligitan dimenangkan oleh Malaysia. Hal ini terjadi karena ada perubahan garis batas terluar yang diakibatkan atas masuknya Sipadan Ligitan ke Malaysia. Sayangnya, persoalan perbatasan selalu hanya menjadi hak negara karena isu perbatasan menjadi isu high politic. Negara hampir tidak pernah melakukan diseminasi informasi mengenai diplomasi perbatasan ataupun kuliah umum mengenai persoalan perbatasan dan pengelolaan perbatasan negara. Isu perbatasan negara baru sedikit dibuka pada masa Hasan Wirajuda melalui perkuliahan umum, jurnal ilmiah seperti Opinio Juris dan Tabloid Diplomasi. Sayangnya, media tidak pernah menjadikan mereka rujukan dan sebaliknya media sangat jarang menjadi partner strategis dalam memelihara identitas geografis.

Indonesia baru bereaksi setelah sejumlah pelanggaran dilakukan Malaysia pada tahun 2005, 2007, 2009 juga 2015. TNI mendesak Kementerian Luar Negeri untuk melayangkan protes kepada Malaysia atas pelanggaran yang dilakukan. Wirajuda sendiri membuat pernyataan atas Blok Ambalat pada tahun 2009 dengan menyebutkan bahwa Blok Ambalat bukan konflik kedaulatan tapi hak berdaulat. Blok Ambalat adalah landas kontinen bukan perairan wilayah. Tidak ada satupun negara di dunia yang punya kedaulatan pada landas kontinen. Hak pada landas kontinen hanyalah melakukan konsesi, ekploitasi dan ekplorasi sumber daya alam. Sedangkan kedaulatan ada pada laut wilayah yang berjarak 12 mill dari pantai. Perbedaan kepentingan atas pengelolaan perairan Ambalat bukan hal yang mudah dipahami oleh publik tetapi di sisi lain tidak ada upaya untuk mengedukasi dalam hal sengketa wilayah ini. Hal yang sama juga terjadi pada persoalan Tanjung Datu. Persoalan yang sudah lama berada dalam OBP tersebut muncul karena kekhawatiran yang tidak berdasar atas perbatasan Indonesia-Malaysia di Tanjung Datu oleh seorang anggota dewan (Malau\&Priatmojo, 2011).

Hal yang sama terjadi pula dalam klaim budaya. Indonesia cenderung menampakkan sikapnya yang reaktif dengan sibuk melakukan protes dan mencatat klaim budaya yang dilakukan oleh Malaysia. Sementara 'klaim' terjadi karena kebijakan ekonomi/pariwisata Malaysia yang mendorongnya melakukan inventarisasi budaya yang 
tersebar di Semenanjung (Supanggah, 2011). Aktifitas ini menimbulkan rasa khawatir akan kehilangan budaya yang sejatinya hanya akan hilang jika tidak dipelihara. Situasi semacam ini menunjukan bahwa Indonesia tidak memiliki rencana strategis dalam hal pemeliharaan budaya lokal sebagai identitas nasional.

Sikap reaktif juga ditunjukkan oleh negara atas persoalan tenaga kerja migran Indonesia di Malaysia. Peristiwa tenaga kerja migran yang dipulangkan paksa oleh Malaysia dan mengakibatkan sejumlah orang meninggal dunia di tahun 2002 dan 2005 sesungguhnya tidak perlu terjadi jika negara dengan segera menata ulang skema tenaga kerja migran. Kebijakan menata ulang tenaga kerja migran telah dimulai di Malaysia semenjak tahun 1991. Sementara negara baru mendirikan BNP2TKI di tahun 2007. Sayangnya, kebijakan tersebut belum menyentuh persoalan mendasar tenaga kerja migran Indonesia. Kapabiltas tenaga kerja migran, sektor pekerjaan yang lebih bermartabat dan kesadaran atas hak dan kewajiban mereka sebagai individu belum cukup diperhatikan oleh negara yang menganggap mereka sekedar komoditas ekonomi. Penyadaran serta pendampingan lebih banyak kemudian dilakukan oleh Migran Care sebagai salah satu dimensi domestik yang memiliki kepedulian yang berkesinambungan atas persoalan tenaga kerja migran Indonesia. Sedang penguatan identitas sebagai warga Indonesia lebih dilakukan oleh kelompok-kelompok sosial Indonesia di Malaysia seperti Pasomaja dan Permai.

Sikap-sikap reaktif yang cenderung negatif dalam memengaruhi relasi antar negara juga terlihat dilakukan oleh netizen. Sebagaimana isu Ambalat, isu Pendet juga memanaskan ruang-ruang siber yang didominasi oleh kelompok muda. Kata-kata cacian dan hinaan seringkali dipergunakan seperti 'Malingsia' dan 'Ganyang Malaysia'. Sebuah survey dilakukan oleh Malaysia, ditemukan terdapat 13.000 pengguna internet telah mempergunakan istilah 'Malingsia', 'Maling Asia', 'CrazyMalay' dan 'Maling Shit' (Maksum\&Bustami, 2014). Sejumlah demonstrasi dan sweeping terhadap warga Malaysia pun merupakan bentuk-bentuk sikap reaktif yang dimaksudkan oleh Bendera (lembaga swadaya masyarakat yang menjadi pencetus dan penggerak sweeping) untuk memberikan pesan kepada Malaysia agar tidak bertindak berlebihan terhadap budaya Indonesia. Hal tersebut juga menjadi pesan bagi negara untuk menempuh diplomasi yang lebih tegas atas tindakan Malaysia yang dinilai semena-mena dan sombong (Wawancara dengan Adian Napitupulu di Jakarta, tanggal 26 April 2015).

Sikap dan tindakan reaktif ini biasanya hilang setelah mendapat tanggapan dari Malaysia dan atau ketika media tidak lagi secara masif memberitakannya. Sikap reaktif juga tidak diikuti oleh tindakan konkret dalam memelihara persoalan yang menjadi polemik secara berkesinambungan. Dalam hal ini budaya misalnya, sikap reaktif tidak menghasilkan upaya-upaya preservasi budaya yang terorganisasi dengan baik. Sikap dan tindakan reaktif sifatnya tidak permanen dan tidak berkelanjutan.

Karakter kedua yang nampak pada diplomasi publik Indonesia adalah inferior. Adler mengungkapkan perasaan inferior muncul ketika seseorang merasa tidak memiliki kemampuan yang cukup sehingga ia merasa direndahkan atau bahkan diabaikan/tidak dianggap oleh orang lain. Perasaan inferior ditemukan pada mereka yang merasa gagal, merasa tidak memiliki harga diri dan atau sesuatu yang membuat orang lain merasa hormat. Dampak dari perasaan inferior lebih mengarah pada perilaku yang negatif bahkan cenderung agresif (Kenchappanavar, 2012).

Perasaan inferior terkait dengan rendahnya harga diri yang dimiliki seseorang atau sekelompok orang. Kernis menyebutkan bahwa harga diri merupakan salah satu bentuk psikologi penting dalam kehidupan sehari-hari seseorang; harga diri menunjukkan bagaimana seseorang melihat dirinya sendiri, yang merefleksikan dan memengaruhi interaksi yang sedang berjalan antara ia dan lingkungannya serta orang-orang yang ditemuinya (Kernis, 2003).

Mengacu pada pendapat Alicia D. Cast dan Peter J. Burke (2002), tidak ada konsep yang satu mengenai harga diri. Namun, pada penelitiannya, harga diri memiliki keterkaitan antara individu dengan kelompok di mana ia berada. Harga diri menurut Cast dan Burke dapat dipandang sebagai tiga hal, yaitu sebagai sebuah hasil, sebuah upaya pertahanan diri dan juga dapat dilihat sebagai sebuah motif. Sebagai sebuah hasil, harga diri merupakan hasil dari sebuah proses verifikasi diri seseorang di dalam sebuah kelompok. Proses verifikasi atas identitas ini menumbuhkan rasa percaya diri dan rasa kelayakan diri 
seseorang sebagai bagian dari kelompok.

Harga diri juga dapat dilihat sebagai sebuah alat pertahanan diri. Ketika seorang individu tidak dapat melakukan verifikasi terhadap identitasnya, harga diri akan memproduksi sebuah usaha untuk melindungi dirinya sendiri dari tekanan karena ketidakmampuannya melakukan verifikasi diri tersebut. Maka, kadangkala harga diri dianalogikan sebagai 'reservoir of energy'. Harga diri sangat responsif terhadap perubahan dalam situasi sosial. Ketika perubahan-perubahan ini mempengaruhi verifikasi diri, maka harga diri akan menurun. Ketika proses verifikasi terhadap identitas terganggu, tekanan akan muncul berupa respon emosi yang bersifat negatif seperti kegelisahan, depresi, dan kemarahan. Hal ini akan memotifasi seseorang untuk mengurangi gangguan dengan merubah persepsi agar sejalan dengan identitas standar. Harga diri dapat juga dimaknai sebagai motif karena verifikasi diri dalam kelompok dapat mendorong munculnya motif individu untuk membentuk dan menjaga hubungan yang mampu melakukan verifikasi terhadap identitas yang ada.

Terkait dengan perasaaan inferior yang diungkapkan dengan kebencian terhadap kelompok lain terjadi ketika ia merasa tidak lebih baik dari orang lain atau kelompoknya tidak lebih baik dari kelompok yang lain. Artinya harga diri juga berkaitan dengan perasaan yang muncul karena adanya perbandingan dengan individu atau kelompok lain. Dengan demikian, kadangkala perasaan harga ini dikelola dengan cara menjaga persepsi bahwa kelompok lain lebih buruk/rendah dibanding kelompoknya. Apakah persepsi tersebut didasarkan oleh hal yang nyata atau tidak, namun persepsi tersebut dapat menjadi ancaman bagi kepentingan kelompok lain. Ancaman terhadap kepentingan kelompok tersebut menimbulkan rasa takut dan permusuhan pada kelompok lain. Harga diri bangsa meningkat ketika ia direndahkan dan didiskriminasikan oleh kelompok lain, mendapat kekerasan dari kelompok bangsa lain atau respon yang tidak menyenangkan lainnya. Bahkan, hal ini dapat menimbulkan sebuah gerakan nasional untuk melawan respon yang dianggap telah merendahkan tersebut (Kernis, 2003).

Perasaan inferior yang ditunjukkan oleh perilaku yang negatif tidak hanya dipicu oleh periode sejarah yang menempatkan Indonesia tidak lagi menjadi abang bagi adiknya, Malaysia. Hubungan saudara serumpun pun dianggap tidak lagi relevan bagi hubungan kedua negara. Merujuk Abubakar Eby Hara, hal tersebut terjadi karena hilangnya perasaan atas nasib yang sama (common fate) (Hara, Tanpa Tahun). Usulan-usulan untuk merubah bentuk hubungan dari saudara abang dan adik pun dimulai pada masa Mahathir ketika kebijakan pembangunannya menunjukkan hasil yang positif. Hal tersebut juga memberikan kepercayaan diri untuk memainkan peran yang jauh lebih besar lagi bagi Malaysia dalam diplomasi internasional. Kampanye tentang perlunya 'smart partnership' atau kerja sama yang cerdas, fairness dan equal serta 'Malaysia boleh' dikumandangkan, yang berarti merubah status quo kebijakan politik yang dijalankan pada masa PM Tun Abdul Razak dan Tun Hussein On.

Perasaan inferior yang tumbuh akibat gagal melakukan verifikasi kembali identitas yang terlanjur melekat di benak mereka menumbuhkan emosi yang negatif. Perasaaan inferior terjadi ketika diri merasa tidak lebih baik dari orang lain atau kelompoknya tidak lebih baik dari kelompok yang lain. Terlebih lagi ketika orang Indonesia di Malaysia hanya menduduki warga kelas dua yang bekerja sebagai buruh kasar. Harga diri sebagai bangsa yang dahulu merupakan bangsa yang memiliki posisi yang lebih baik (direpresentasikan sebagai abang) terganggu. Tidak jarang perasaan harga diri dikelola dengan cara menjaga persepsi bahwa kelompok lain lebih buruk/rendah dari kelompoknya. Dengan demikian perasaan inferior sering ditunjukkan dengan ujaran yang merendahkan seperti 'Malingsia', 'Bangsa Pencuri', 'The Truly Maling Asia' dan lain sebagainya. Kekhawatiran yang berlebihan menunjukkan perasaan inferior bangsa Indonesia yang merasa rendah diri atas perubahan situasi sosial ekonomi Malaysia.

Perubahan sosial tersebut menjadikan harga diri menjadi sangat rentan. Kekerasan yang dilakukan terhadap tenaga kerja Indonesia dan perilaku yang dianggap diskriminatif terhadap warga Indonesia yang tinggal di Malaysia, diinterpretasikan sebagai perilaku yang menyinggung harga diri bangsa. Direpresentasikan melalui diksi 'Indon', harga diri bangsa Indonesia mudah sekali terusik oleh diksi tersebut. Selain karena fakta menunjukkan bahwa orang Indonesia menduduki sektor pekerjaan 3D (Dirty, Dangerous, and Demeaning), sebutan Indon terhadap mereka 
seakan merujuk pada level sosial mereka tersebut. Gambaran negatif yang mengikuti kata 'Indon' berkembang ketika media massa di Malaysia seringkali mempergunakan kata tersebut untuk menyebut pekerja asal Indonesia yang berperangai buruk (Zakiah, 2012). Misalnya media massa di Malaysia yang mengambil tajuk '25.000 Pekerja Indonesia Bawa Penyakit Setiap tahun', 'Pekerja Asing Biadab', 'Orang Indon Mengganas'. Akibatnya pemberitaan itu telah menciptakan opini negatif di kalangan masyarakat Malaysia terhadap orang Indonesia (Kelana\&Hara, 2009:103).

Sementara itu pernyataan 'Peningkatan Jenayah' (peningkatan kriminalitas) oleh pejabat dan polisi Malaysia dengan sangat mudah dikonotasikan dengan 'Indon' sebagai pelakunya oleh media massa Malaysia, padahal survey oleh ILMIA (2013) tidak menunjukkan bahwa peningkatan kriminalitas dilakukan oleh pekerja migran khususnya dari Indonesia. Pekerja migran pun tidak jarang digambarkan dengan pilihan kata 'diburu' oleh Rela untuk menunjukkan betapa hinanya mereka (Nasir, 2011). Pekerja Indonesia pun selalu dikonstruksi sebagai kelompok PATI, Pekerja Tanpa Ijin, yang kerap menghiasi berita mengenai pekerja Indonesia. Sebutannya pun tidak jarang diganti dengan 'pendatang haram'. Hal ini menimbulkan kesan bahwa PATI merupakan suatu persoalan yang seringkali mengganggu kehidupan sosial dan budaya dalam negeri Malaysia karena berita PATI seringkali ditempatkan pada halaman dalam negeri (Zakiah\&Fardiah, 2012:84).

Menariknya, makna negatif yang melekat pada kata 'Indon' tidak ditemukan pada persepsi diri pekerja Indonesia yang ada di Malaysia. Seringkali pekerja Indonesia menyebut diri mereka 'Indon'. Pada serangkaian percakapan dengan beberapa pekerja (kilang) Indonesia di Penang (Wawancara dengan beberapa pekerja kilang di Imigrasi Penang, Malaysia sepanjang September 2015) berkali-kali mereka bercerita dengan mempergunakan kata tersebut untuk menunjuk diri mereka. Berbeda dengan pekerja profesional, kata 'Indon' tidak pernah dipergunakan dalam percakapan. Tohakim berpendapat, penggunaan kata 'Indon' oleh orang Indonesia sendiri terjadi karena kebiasaan lingkungan sekitar dan bagi pekerja sendiri tidak merasakan dampak negatifnya, tidak merasa direndahkan, hanya untuk membedakan mereka dengan pekerja yang berasal dari negara lain. Mereka hanya tahu ketika diberitahu (Ket: tahu jika 'Indon' bermakna peyoratif jika diberitahu) (Wawancara dengan Tohakim (pekerja Indonesia di Malaysia) di Kulim, tanggal 16 September 2015).

Kata 'Indon' sendiri adalah akronim yang mulanya dipergunakan untuk memudahkan menyebut Indonesia. Kata 'Indon' sama sekali tidak bermakna negatif (Wawancara dengan Musni Umar di Jakarta, tanggal 26 April 2015 dan wawancara dengan Mahyudin Al Mudra di Yogyakarta, tanggal 30 Juni 2015). Seperti halnya orang Indonesia, orang Malaysia pun suka menyingkat-nyingkat, Bangladesh menjadi 'Bangla', orang Vietnam menjadi 'Nam' dan Indonesia menjadi 'Indon'. 'Indon' sekedar pernyataan deskriptif saja bukan pernyataan evaluatif. Sementara Al Azhar, seorang peneliti senior pada Pusat Penelitian Kebudayaan dan Kemasyarakatan Universitas Riau, mencoba melacak makna antropologis melalui lingkup akademik dan orang/lingkungan yang disebut 'Indon' dan Al Azhar tidak menemukan penjelasan apapun dari mereka. Kata 'Indon' adalah istilah untuk individu atau kelompok orang warga negara Indonesia yang bermigrasi ke Malaysia (terutama untuk tujuan ekonomi) dan hidup di pemukiman-pemukiman yang disebut dengan 'setinggan' (bangunan atau rumah-rumah darurat). Mereka bekerja sebagai buruh kasar di kebun-kebun, pabrik-pabrik, bangunan-bangunan dan rumah tangga (Al Azhar, 2011:229).

Perasaan inferior sebagai akibat dari hal tersebut dapat ditemukan dalam sejumlah isu bilateral. Isu Sipadan dan Ligitan misalnya menjadi salah satu munculnya inferioritas yang terus digaungkan oleh media. Peristiwa tersebut kemudian menjadikan publik lebih mudah curiga dan khawatir atas pelanggaran wilayah yang dilakukan oleh Malaysia. Demikian pula dengan isu klaim budaya yang sangat mudah mendorong reaksi negatif karena kekhawatiran atas hilangnya budaya sebagai identitas kultural. Sementara di Malaysia, budaya tersebut menjadi bagian dari komoditas ekonomi yang memperoleh ruang besar untuk dikembangkan. Kementrian Kebudayaan, Kesenian dan Warisan Budaya Malaysia mempersiapkan dukungan berupa sejumlah besar dana bagi kelompok-kelompok budaya yang mencatatkan seni budayanya. Penggunaan budaya sebagai komoditas ekonomi tentu saja menjadi 
persoalan bagi kelompok kultur terkait karena didalamnya terletak identitas diri masyarakat di mana budaya tersebut berkembang. Baik seni tari, musik atau seni rupa atau jenis kesenian lainnya merupakan hasil dari interaksi individu dalam bertukar nilai dan membentuk nilai bersama.

Namun demikian, pada kelompok-kelompok tertentu, karakter inferior tersebut tidak muncul dalam praktik relasi antar warga antar negara. Mereka adalah kelompokkelompok yang memiliki relasi langsung (people to people contact) dan kelompok-kelompok yang secara reguler berbagi ide dan informasi mengenai satu hal tertentu. Kelompok budaya misalnya secara reguler menggelar pertemuan untuk berbagi informasi mengenai perkembangan budaya dan mempertukarkan pertunjukan seni budaya. Mereka yang berlatar belakang akademik juga secara reguler bertemu dan berinteraksi untuk mempertukarkan bermacam ide dan riset yang mereka lakukan. Interaksi reguler yang berlangsung dalam rentang waktu yang cukup lama menumbuhkan saling kesepahaman dan self restrain yang secara naluriah hadir karena kedekatan emosi.

Dalam gagasan relationship building, Zaharna (2009), Leonard (2002) dan juga McDowell (2008) memiliki kesamaan pemahaman bahwa perlunya bentuk-bentuk keterlibatan langsung dari negara dan aktor non negara dalam kegiatan pertukaran ide. Hal tersebut dapat dilakukan dalam berbagai bentuk dengan satu asumsi bahwa kegiatan yang melibatkan aktor secara langsung dalam hal pertukaran ide dan nilai budaya dapat menumbuhkan empati yang lebih baik bagi setiap partisipan. Dalam jangka panjang proyek-proyek semacam ini diyakini akan menumbuhkan hubungan yang lebih baik antar negara. Tekhnologi komunikasi memang telah memberikan kesempatan yang jauh lebih baik bagi setiap orang untuk berbagi ide dan menumbuhkan pengetahun yang lebih baik antara satu dengan yang lain.

Kegiatan yang banyak dibuat dalam relationship building ini adalah international education exchange. Mengacu pada konsep Hugh M. Jenkins international educational exchange adalah sebuah kerangka kerja sama yang melibatkan dua atau lebih anggota, siswa, institusi pendidikan dan juga pemerintah serta intitusi swasta yang menyediakan dana pendidikan (Lima, 2007). Dalam kaitannya dengan diplomasi publik, international education ex- change merupakan salah satu cara untuk meningkatkan imaji positif negara dengan jalan memberikan kesempatan kepada generasi muda dari negara lain untuk melihat dan berkomunikasi secara langsung di negara-negara penyedia beasiswa. Dengan demikian mereka dapat bersentuhan langsung dengan system politik, budaya, dan nilai masyarakat dari negara yang berbeda. Pertukaran semacam ini juga dapat menghindarkan prejudice yang muncul diantara dua masyarakat yang tidak pernah bertemu secara langsung, di mana gambaran yang terbangun dalam benak mereka hanyalah gambaran yang dibingkai oleh media atau pihak ketiga yang sarat dengan kepentingan pribadi.

Praktik-praktik relasi langsung semacam ini terjadi pada masyarakat perbatasan yang menunjukkan karakter yang berbeda dengan mereka kelompok domestik yang mempergunakan media sebagai jembatan relasi dalam isu perbatasan. Kelompok masyarakat perbatasan yang menjalin interaksi langsung dengan masyarakat perbatasan di Serawak cenderung memilih sikap-sikap yang kooperatif melalui makna perbatasan yang mereka bangun sendiri. Pada pasca reformasi, hubungan adat ini kemudian dijembatani oleh DAD (Dewan Adat Dayak) dan SNDU (Sarawak National Dayak Union) melalui sejumlah kerja sama sosial dan budaya. Selain Gawai Dayak, kedua lembaga ini juga menyelenggarakan kerja sama lain seperti pendidikan dan kesehatan. Demikian pula dengan mereka kelompok akademik dan budaya yang secara reguler menjalin relasi melalui sejumlah pertemuan dan kajian ilmiah serta budaya seperti Balai Melayu di Yogyakarta yang memelihara identitas Melayu melalui sejumlah kajian dan penerbitan, Malindo Research Centre dan juga sejumlah konsorsium akademik lain. Identitas serumpun yang masih terus dilanggengkan dalam benak mereka yang menjalin relasi tersebut mengantarkannya pada sikap-sikap yang jauh lebih positif.

\section{SEJARAH SEBAGAI KONSTRUKSI MEMORI KOLEKTIF VS DAMPAK PERUBAHAN KEBIJAKAN EKONOMI POLITIK MALAY-} SIA

Sejarah kedua bangsa memberikan dampak yang cukup besar dalam pembentukan ingatan bersama masyarakat Indonesia yang memengaruhi pola hubungan dan interaksi kedua negara/diplomasi publik. Memori kolektif ini terus 
dipelihara melalui sejumlah instrumen pengantar memori baik mainstream media (buku teks dan surat kabar) maupun new media (media sosial). Kansteiner berpendapat bahwa memori kolektif tidaklah semata-mata merupakan catatan sejarah, meskipun terbangun dari material atau obyek yang sama, memori kolektif merupakan pemaknaan kembali secara sadar atas fenomena yang terjadi dan diabsorsi kembali secara tidak sadar oleh masyarakat sehingga mereka memiliki makna yang sama atas sebuah fenomena. Hal ini, menurut Kansteiner, termanifestasikan dalam bentuk pernyataan dan juga aksi (Kansteiner, 2001:180). Individu dapat mengakses dan akhirnya memiliki sebuah kolektif memori dan juga dapat menyerap sebuah pemaknaan ulang sebuah fenomena melalui komunikasi. Dengan demikian, ia mengikat anggota masyarakat untuk merasa memiliki masa lalu yang sama. Kesadaran akan sejarah pun dapat dimiliki melalui proses ini (Fukenstein, 1989).

Memori kolektif dapat dimiliki secara bersama-sama oleh anggota masyarakat melalui proses dialog atau komunikasi. Mengutip Halbwachs, Green (2004:38) menyatakan bahwa individu dapat mengingat melalui dialog yang terbangun di dalam sebuah kelompok sosial. Bahkan ketika seorang individu tidak mampu menerima atau tidak mengingat sebuah pengalaman atau kejadian, komunitas sosial akan membuat sebuah kondisi di mana individu yang bersangkutan dapat menerima pengalaman tersebut dalam ingatannya melalui apa yang disebut dengan 'affective community'.

Proses melekatnya sebuah kolektif memori pada sebuah kelompok masyarakat dapat mendorong munculnya identitas kolektif. Hal ini terjadi karena pada sebuah memori kolektif dapat membawa sebuah impresi emosi atau sebuah pesan moral yang dapat membuat anggota kelompok merasa memiliki ikatan yang sama. Polleta dan Jasper (2001:285) mendefinisikan identitas kolektif sebagai berikut.

"...individual's cognitive, moral, and emotional connection with broader community, category, practice, or institution. It is a perception of a shared status or relation which may imagined rather than experienced directly and it is distinct from personal identities, although it may form part of personal identity."
Sekelompok individu dapat memiliki identitas yang sama atau memiliki identitas kelompok melalui proses berbagi pengalaman dan atau melalui sebuah proses kolektif memori, karena setiap ingatan pada setiap fenomena sesungguhnya telah membawa makna atau pesan dan tidak sekedar berupa himpunan fakta masa lalu. Merujuk pada pendapat Hynes bahwa 'memory is mental faculty by which we preserve or recover our pasts, and also the events recovered' (Green, 2004:38), maka sekali lagi memori tidak sekedar sejarah yang tersimpan di dalam kepala melainkan sebuah kesadaran yang muncul terhadap sebuah fenomena yang terjadi di masa lalu. Dengan demikian, memori kolektif bahkan dapat mempersatukan kelompok karena ia dapat melekatkan identitas bersama.

Memori kolektif bangsa Indonesia atas kebesaran bangsanya dimulai sejak masa sebelum kedatangan kolonial. Ide mengenai bangsa yang besar, kerajaan yang memiliki pengaruh politik lebih dari luas geografis Indonesia saat ini selalu dihidupkan dalam buku-buku teks dan juga dialog. Kebesaran Sriwijaya di masa lalu sebagai cikal bakal kerajaan Melayu terbesar sepanjang sejarah yang dilanjutkan oleh kerajaan Melayu di Riau menanamkan ingatan akan peradaban nenek moyang bangsa Indonesia yang sangat maju. Kemasyuran Kerajaan Riau dan sastra Melayu di masa Raja Ali Haji pun menjadi salah satu pondasi untuk membentuk imaginasi tentang bangsa dengan rumpun yang sama, Melayu. Dan kemudian hal ini dilanggengkan dalam politisasi budaya 'Serumpun' pada masa menjelang kemerdekaan dan dihidupkan kembali pasca Konfrontasi.

Demikian pula dengan ingatan akan heroiknya Soekarno melawan neo kolonialisme dan 'antek-antek imperialis' pun selalu dilanggengkan dalam ruang ingatan publik. Dalam penelitiannya, Suwirta menjelaskan bahwa buku teks sejarah di sekolah telah membingkai pemahaman dua bangsa ini, Indonesia dan Malaysia dalam perspektif yang berbeda mengenai masa lalunya. Suwirta menemukan adanya perbedaan bagaimana Indonesia dan Malaysia melihat peristiwa konfrontasi. Hal ini kemudian sangat berpengaruh pada bagaimana orang Indonesia sekarang melihat orang Malaysia sekarang. Pada buku teks yang ada di Indonesia, peristiwa 'ganyang Malaysia' tersebut dijelaskan secara logis meski ditimpali dengan kalimat yang 
menjelaskan bahwa masa itu adalah catatan buruk bagi sejarah Indonesia-Malaysia. Logika mengambil sikap konfrontatif memiliki kekuatan, membekas dalam benak banyak anak-anak pembaca buku teks tersebut, terutama bahwa Indonesia sangat menentang kolonialisme dan Malaysia dianggap sebagai negara yang melanggengkan hal tersebut. Sedangkan pada buku-buku teks di Malaysia, cerita semacam ini tidak terlalu banyak diulas, mereka hanya mengungkapkan bahwa peristiwa itu merupakan hasil dari kebijakan pemerintah yang tidak kondusif maka pergantian pemerintahan baik di Indonesia dan Filipina sebagai peristiwa yang dianggap memberikan kontribusi cukup baik bagi hubungan yang lebih harmonis di antara kedua negara (Andi Suwirta. 2010).

Selain itu, bagaimana Indonesia ditempatkan atas Malaysia di masa Soeharto. Posisi yang subordinan sebagai abang secara naratif selalu didengungkan melalui 'serumpun' yang kemudian diamalkan dalam aksi/tindakan. Indikator keberhasilan tindakan Soeharto kala itu adalah sikap Tun Abdul Razak yang memelihara hubungan konsultatif dengan Indonesia terkait dengan kestabilan wilayah regional (Kelana dan Hara, 2009) yang juga dilihat sebagai sebuah kesediaan Malasyia untuk menerima posisi yang asimetris atau self induced subordination. Malaysia secara tidak langsung mengakui status Indonesia sebagai abang, negara yang memiliki kuasa atas hubungan keduanya (Abd Razak et.al., 2013). Terlebih ketika Indonesia menjadi pihak yang mengirimkan sejumlah besar guru dan dosen ke Malaysia pada tahun 70an untuk menggantikam posisi mereka yang berasal dari Inggris, Australia dan Amerika karena perubahan kebijakan bahasa.

Kejayaan Indonesia di masa lalu ini kemudian menjadi identitas di mana bangsa ini selalu melihat dirinya sebagai bangsa yang lebih dominan atas Malaysia. Melalui buku, artikel dan juga perbincangan sehari-hari, memori kolektif sebagai bangsa yang besar terus dipelihara. Pada hubungan Indonesia-Malaysia saat ini, frasa 'Ganyang Malaysia' dipergunakan kembali untuk memelihara gambaran Indonesia yang lebih unggul dibandingkan Malaysia. Meski telah berbeda generasi, memori kolektif mampu memberikan biografi yang sama melalui 'vehicle of memory' (instrumen pengantar memori), dalam bentuk buku, film, perayaan dan lain sebagainya (Green, 2004:27). Instrumen pengantar memori yang cukup efektif saat ini adalah tulisan dan atau percakapan yang terjadi melalui internet (baik blog atau media sosial) yang membantu perbincangan sehari-hari menjadi lebih luas, intens dan masif dalam membentuk realitas dan membaginya dengan yang lain. Instrumen pengantar memori melalui internet misalnya adalah blog atau mini blog yang dikarakteristikkan oleh semacam jurnal yang bertutur secara kronologis mengenai sebuah fenomena yang dibingkai oleh opini personal, terkadang dibumbui oleh sejumlah video, meme, dan tautan lain yang terkait (Ham, 2010:97).

Blog memungkinkan informasi dan opini dapat disebarkan secara cepat kepada publik dibandingkan media lain. Pemilik blog dapat setiap saat mengunggah tulisan mereka dengan cepat tanpa ada kontrol editorial dari siapapun dan tanpa ada prasarat atas keobyektifan informasi dan ketidakbiasan data. Blog memiliki beragam topik dengan beragam sumber informasi. Blog dan video tersebut dapat menciptakan gerakan nyata bagi sejumlah besar orang. Bagi warga diaspora, internet seakan menciptakan 'payung virtual' bagi mereka yang tersebar di beberapa negara. Kombinasi antara teks dan gambar menjadi sebuah gambaran yang Nampak nyata bagi warga diaspora (Chan, 2005). Dengan demikian, internet juga mampu memperkuat identitas nasional seseorang (Eriksen, 2007). Bagi aktivis gerakan sosial maupun politik, internet mampu menawarkan kesempatan yang sama dalam menggerakkan orang seperti halnya di dunia nyata, karena mereka juga dapat tertikat pada satu nilai atau identitas yang sama (Postmes dan Brunsting, 2012). Dalam hal ini, blog, video, dan juga meme terkait dengan ide yang melibatkan isu bilateral Indonesia Malaysia dapat menjadi salah satu bentuk vehicle of memory yang sangat mudah melekat di benak publik dan menumbuhkan kembali emosi atas Malaysia.6

Demikian pula dengan mainstream media, surat kabar dan televisi, melanggengkan ide melalui pilihan diksi dan pembingkaian berita dalam benak publik. Media membingkai ulang isu Sipadan Ligitan dalam setiap persoalan perbatasan Indonesia Malaysia. Bahkan tidak jarang ceritanya menjadi berbeda dengan kebijakan dan pandangan Kementrian Luar Negeri.7 Riset Pertiwi (2014) secara tidak langsung menggambarkan bahwa informasi yang 
diberikan media cenderung menggiring persepsi publik pada aktifitas yang bertolak belakang dengan kebijakan Kementrian Luar Negeri. Bahkan media terlihat sangat kuat menanamkan informasi yang berbeda di saat Kementrian Luar Negeri memberikan informasi yang sangat terbatas. Akibatnya gap antara informasi yang disampaikan negara dengan media menjadi sebuah pertanyaan besar publik atas kesungguhan dan kemampuan negara dalam menyelesaikan persoalan perbatasan.

Imaji yang terus terpelihara tersebut nyatanya tidak mampu menghadapi dampak kebijakan ekonomi Malaysia yang mengantarkannya menjadi negara yang lebih baik secara sosial dan ekonomi. NEP atau the New Economic Policy mulai dijalankan pada tahun 1970 oleh Malaysia. NEP bertujuan untuk menghilangkan kemiskinan terutama yang terjadi pada kelompok ras tertentu dengan jalan meningkatkan lapangan kerja dan meningkatkan fasilitas publik. Ia juga berusaha merestrukturisasi ketimpangan ekonomi dan juga distribusi pendapatan di antara kelompok etnis yang berbeda. Hal ini membuka peluang bagi orang Melayu untuk bekerja di sektor selain sektor pertanian. Pada sektor pendidikan, pemerintah Malaysia menyuntikkan dana yang cukup besar untuk meningkatkan kapabilitas warga Melayu dalam bidang industri dan perdagangan. NEP memungkinkan negara untuk mengintervensi sumber-sumber ekonomi dan mengontrol bisnis. Akses terhadap sumber-sumber ekonomi ini kemudian dimanfaatkan oleh negara untuk memperoleh dukungan publik. Sejak dijalankan pada tahun 1970, NEP berhasil mengurangi tingkat kemiskinan secara signifikan dan meningkatkan standar hidup masyarakat Malaysia.

Selain pengaruh perubahan ekonomi yang turut merubah sektor pekerjaan bagi orang Indonesia di Malaysia, perubahan visi pemerintah Malaysia juga berdampak atas perubahan pandangan kaum muda Malaysia terhadap dirinya. Melalui sejumlah kebijakan, Malaysia perlahan merubah identitas dirinya melalui wacana 'Look East'8, 'Malaysia Boleh'9, 'New Asia'10, dan 'Smart Partnership'11. Hal ini tidak saja memberikan kemajuan ekonomi tetapi juga kebanggaan dan rasa percaya diri yang lebih bagi pemuda Malaysia.

Sementara itu yang terjadi justru sebaliknya bagi orang Indonesia yang bekerja di Malaysia. Dampak dari NEP yang dialami oleh Indonesia adalah meningkatnya jumlah tenaga kerja migran Indonesia di Malaysia. Sayangnya, pola pembagian sektor pekerjaan bagi warga bumiputera lebih banyak menyisakan sektor 3 D's Job bagi pekerja Indonesia. Pekerja profesional yang berasal dari Indonesia yang semula mendominasi pekerja di Malaysia yaitu sebagai tenaga pengajar dan atau tenaga profesional lainnya semakin sedikit jumlahnya. Bagi generasi muda di Malaysia, situasi ini memberikan gambaran nyata bagi mereka mengenai orang Indonesia. Bagi mereka orang Indonesia adalah orang miskin dan sumber kriminalitas di Malaysia. Pengaruh media dan juga kebijakan negara menggeser gambaran mengenai orang Indonesia sebagai abang serumpun yang layak disegani. Gambaran mengenai keserumpunan yang subordinatif tidak ditemukan dalam benak kaum muda Malaysia. Kelompok muda di Malaysia lebih banyak mengenal Indonesia sebagai pekerja kasar dan rumah tangga saja (Wawancara dengan Mahyudin Al Mudra di Balai Melayu, Yogyakarta, tanggal 30 Juni 2015). Hal ini kemudian mewakili gambaran mereka mengenai Indonesia dan sulit untuk menempatkan Indonesia sebagai saudara tua.

Kebijakan sekuritisasi pekerja migran oleh Mahathir semakin mempertegas garis batas antara mereka masyarakat Malaysia yang memiliki tingkat sosial dan ekonomi yang lebih baik dengan orang Indonesia yang bekerja sebagai pekerja kasar di Malaysia. Terlebih lagi ketika tenaga kerja migran dianggap menjadi sumber peningkatan jenayah (kriminalitas) di Malaysia. Mahathir sendiri sangat tegas terhadap pekerja asing termasuk Indonesia yang membuat kerusuhan di Malaysia. Perubahan situasi yang berpengaruh terhadap perubahan pandangan tersebut mendorong Malaysia pun sedikit demi sedikit mengubah pola hubungannya terhadap Indonesia.

Perubahan sosial ekonomi ini semakin menipiskan Serumpun sebagai perekat hubungan bilateral kedua negara. Serumpun dengan sengaja dikonstruksikan untuk menyatukan dua wilayah yang dahulu merupakan jajahan Inggris dan Belanda. Sayangnya pondasi geografis tersebut gagal menyatukan keduanya. Ide Serumpun terus berlanjut dengan dikonstruksikan kembali melalui kesamaan budaya Melayu. Hal ini tentu saja merupakan imaginasi saja karena Melayu tidak benar-benar merupakan kesamaan yang dapat 
ditemukan dalam masyarakat Indonesia maupun Malaysia. Di Malaysia, Melayu hanya ditemukan di sebagian warga Malaysia karena sebagian yang lain adalah India dan Cina. Dengan begitu, Serumpun pun hanya dapat diterapkan di sebagain masyarakat Malaysia saja. Begitu juga di Indonesia, Melayu merupakan sebagian etnis saja yang ada di Indonesia. Bahkan, Indonesia sendiri membangun dirinya melalui 'Bhinneka Tunggal Ika' bukan serumpun yang bermakna satu rumpun. Pluralisme di Indonesia pun diikat oleh bahasa Indonesia bukan bahasa Melayu. Politisasi budaya ini semata-mata dibangun dengan muatan politik agar keduanya menempatkan diri sebagai dua bangsa yang mampu memelihara relasi dan menjaga kestabilan regional.

Semakin jauhnya gambaran masyarakat Malaysia di mata orang Indonesia dengan perubahan kondisi sosial ekonomi tersebut cenderung sulit dipahami oleh Indonesia. Pudentia MPSS menggambarkan hal ini sebagai generation gap (Sunarti, 2011). Saat ini generasi muda Malaysia lebih memandang orang Indonesia dengan hal-hal yang dikaitkan dengan keganasan (perampokan) dan tindakantindakan kriminal lainnya, miskin tidak berpendidikan juga pemahaman atas 'balas budi' atau 'mengenang budi'.12 Sementara itu bagi orang Indonesia, orang Malaysia adalah OKB (orang kaya baru) yang arogan (Sunarti, 2011:175) atau manusia angkuh yang diibaratkan kacang lupa pada kulitnya (Nasir, 2011:216).

Selain peran media yang melanggengkan memori koletif bangsa Indonesia dan mejadikan diplomasi publik memiliki karakter yang inferior dan reaktif, kontestasi elit atas politik luar negeri memberikan kontribusi atas rapuhnya diplomasi publik. Persaingan elit atas arah politik luar negeri yang menempatkan diplomasi publik sebagai bagian dari komoditas politik semata melanggengkan karakternya yang reaktif tersebut. Isu bilateral seringkali hanya menjadi bagian dari situasi ini.

Disertasi Muhammad Hadianto Wirajuda menemukan sejumlah data mengenai persaingan presiden dan Kementrian Luar Negeri dalam menentukan arah politik luar negeri Indonesia pada masa reformasi (M.H. Wirajuda, 2014). Hadianto mencatat baik Abdurrahman Wahid maupun Megawati masih memakai pengaruh dan hubungan personalnya dalam mengambil kebijakan luar negeri tanpa berkonsultasi dengan Kementrian Luar Negeri (M.H. Wirajuda, 2014:73-74).

Catatan Hadianto sejalan dengan Connely yang menandai bahwa masa reformasi diwarnai oleh persaingan elit dalam politik luar negeri terutama pada masa Susilo Bambang Yudhoyono (Connelly, 2014). Perombakan pada Kementerian Luar Negeri yang dilakukan pada masa Presiden Megawati di tahun 2011 telah dengan sengaja memindahkan tanggung jawab urusan luar negeri yang sebelumnya banyak dipegang oleh militer kepada Kementerian Luar Negeri. Perubahan tersebut kemudian harus dilanjutkan oleh Presiden Susilo Bambang Yudhoyono (SBY) yang melihat perubahan tersebut sebagai hal yang tidak mudah sebagai mantan militer. Merujuk pendapat Connely, latar belakang militer SBY sebagai militer mendorongnya untuk memindahkan sebagian tanggung jawab Kementrian Luar Negeri ke dalam Istana Presiden dalam rangka mendorong agenda kebijakan luar negerinya dengan membentuk Staf Presiden bidang Hubungan Internasional (SPHI - ada yang menyebutnya SKHI atau Staf Khusus Hubungan Internasional). Staf ini bertindak sebagai penasehat SBY sebagai presiden dan berfungsi sebagai sebagai pos terdepan kementerian luar negeri di Istana yang juga melanjutkan kembali kepentingan/suara militer dalam urusan luar negeri. Melalui kantor ini SBY lebih banyak mengelola kebijakan luar negeri melalui staf khusus yang dipercayanya. Dengan demikan, isi kebijakan luar negeri Indonesia sering merupakan cerminan dari gagasan atau persepsi yang dipegang oleh presiden, sebagai pemimpin kebijakan luar negeri.

Kompetisi antara SBY dan SPHI serta Kementrian Luar Negeri terlihat dalam komentar Hasan Wirajuda dalam mengkritisi Hasjim Djalal yang menjadi staf khusus presiden. Wirajuda menjuluki Djalal sebagai 'rudal tak terarah' atas tindakannya yang kadang-kadang melampaui perannya sebagai staf khusus, yang tidak berwibawa dalam konteks kebijakan luar negeri Indonesia, dan mengganggu pembuatan kebijakan dan implementasinya (M.H. Wirajuda, 2014:82). Peran Djalal dalam kebijakan luar negeri di sisi lain, mencerminkan persaingan antara institusi kebijakan luar negeri di Indonesia dan menunjukkan bahwa hubungan antara Deplu dan SKHI 
tidak selalu sesuai, bertentangan dengan apa yang disarankan oleh mantan anggota staf SKHI. Dengan kata lain, ada hubungan yang kompetitif antara mereka yang membuat, memutuskan, dan melaksanakan kebijakan luar negeri dan mereka yang mempengaruhi keputusan kebijakan luar negeri. Merujuk Hadianto, pada masa SBY kedekatan personal sangat berpengaruh atas kebijakan luar negeri. Bahkan BPPK (Badan Pengkajian dan Pengembangan Kebijakan) Kementrian Luar Negeri pun sulit untuk memainkan peran penting dalam pembentukan kebijakan di dalam tubuh Kementrian Luar Negeri karena dominasi SBY dalam menentukan arah politik luar negeri Indonesia dan pembentukan SKHI.

Persaingan tersebut juga dapat dilihat dalam pementasan identitas Indonesia melalui diplomasi publik. Citra Indonesia yang telah dibangun oleh Wirajuda melalui narasi 'moderat, demokratis, dan progresif' pada akhirnya melemah gaungnya dengan munculnya 'million friends zero enemy'. Citra sebagai bangsa yang bersahabat melalui tagline tersebut disampaikan SBY dalam pidato pengukuhannya sebagai presiden putaran kedua di tahun 2009.

"Indonesia is facing a strategic environment where no country perceives Indonesia as an enemy and there is no country which Indonesia considers an enemy. Thus Indonesia can exercise its foreign policy freely in all directions, having a million friends and zero enemies" (Piccone dan Yusman, 2014).

Upayanya menyisihkan tagline diplomasi publik milik Kementrian Luar Negeri tersebut semata-mata untuk tetap mempertahankan tingginya investasi asing di Indonesia dan pertumbuhan perdagangan yang tinggi (Piccone dan Yusman, 2014). Hal ini juga mendorong SBY untuk memilih sikap yang lunak atas isu bilateral Indonesia-Malaysia. SBY berulangkali menegaskan bahwa penyelesaian persoalan bilateral harus ditempuh melalui jalur perundingan dengan alasan hubungan kesejarahan kedua negara, Indonesia-Malaysia adalah pilar penting ASEAN dan tingginya kerja sama ekonomi yang telah dijalin oleh keduanya (Isi Lengkap Pidato SBY Soal Malaysia, 2010). Pada Sidang Pleno ke-4 Asian Parliamentary Assembly (APA), SBY menyatakan secara tegas bahwa Asia adalah kawasan yang penuh harmoni dan sejahtera. Kawasan yang harmoni dan sejahtera hanya dapat dicapai dengan membangun soft power (Kementrian Sekretariat Negara Republik Indonesia, 2009).

Karakter reaktif lain juga muncul atas pengaruh kontestasi politik dalam negeri seperti yang ditemukan oleh Maksum dan Bustami. Riset Maksum dan Bustami (2014) menengarai adanya pengaruh kepentingan politik dalam negeri atas isu Pendet yang menyeruak di tengah publik domestik dan berakibat pada hubungan yang memanas di antara kedua negara. Dalam artikelnya tersebut, Maksum dan Bustami mengklaim bahwa isu Pendet yang dihembuskan dengan kuat oleh para aktifis LSM Bendera adalah bagian dari strategi PDIP menjelang pemilihan umum di tahun 2009 kala itu. Keterkaitan antara PDIP dan Bendera sangat kuat yang nampak dalam dukungan Bendera dalam menolak keputusan Mahkamah Konstitusi yang memberikan kemenangan pada SBY pada Pemilu 2009. Sebaliknya Megawati menunjukkan kepeduliannya kepada Bendera dalam beberapa kesempatan di depan para aktivisnya melalui sejumlah pernyataan.

LSM yang cenderung radikal ini seakan berusaha menguji nasionalisme SBY dengan isu tarian Pendet yang secara kebetulan menyeruak di tengah publik. Bendera yang terkenal 'anti-Malaysia' cenderung mengambil pendekatan kekerasan karena karakternya terkenal sebagai organisasi kiri dan radikal. Ia bahkan menuduh SBY sebagai agen asing. Sehubungan dengan isu Tarian Pendet oleh Malaysia, Bendera misalnya dengan tegas menyatakan 'akan mengambil sikap sesuai dengan caranya sendiri' dan apabila dilarang maka pemerintah Indonesia (SBY) boleh dianggap sebagai agen asing. Menurut perwakilan Bendera, Mustar Bonaventura, organisasi ini memang sengaja ditujukan sebagai bentuk keresahan terhadap situasi di Indonesia terutamanya berkaitan isu campur tangan asing dalam Pilihan Raya Presiden 2009 termasuk isu tarian pendet oleh Malaysia.

\section{KESIMPULAN}

Diplomasi publik Indonesia yang sarat dengan upaya komunikatif yang negatif cenderung dipengaruhi oleh karakternya yang reaktif dan inferior. Kedua karakter tersebut terbentuk oleh sejarah yang membingkai memori 
kolektif bangsa yang dilanggengkan melalui media, baik mainstream media maupun new media. Sayangnya, memori kolektif tersebut tidak lagi sejalan karena perubahan kondisi Malaysia karena kebijakan ekonomi politiknya. Kontestasi elit dalam politik luar negeri yang menjadikan diplomasi publik rentan sebagai komoditas politik elit semakin menegaskan karakter reaktif diplomasi publik.

Meski demikian, artikel ini mencatat bahwa upaya memelihara relasi bilateral dan identitas nasional masih dipraktikkan melalui bentuk-bentuk diplomasi publik yang positif, yaitu pada mereka yang mempraktikkan hubungan langsung antar warga. Baik mereka pekerja migran maupun mereka yang berada di perbatasan dan kelompok-kelompok akademis dan budaya yang secara reguler melakukan kajian bersama. Catatan penting lainnya adalah, media massa dan media sosial tidak selalu dapat menjadi jembatan yang sempurna karena media memiliki keterbatasan dalam mengantar pesan. Dialog yang dilakukan secara langsung melalui proyek pertukaran warga diyakini dapat dengan lebih baik menumbuhkan saling pengertian bahkan menghilangkan stereotype negatif.

\section{UCAPAN TERIMAKASIH}

Artikel ini merupakan bagian dari kerja studi doktoral di Ilmu Politik Universitas Gadjah Mada atas dukungan dari Kementerian Riset, Teknologi dan Pendidikan Tinggi Republik Indonesia. Terimakasih yang sebesar-besarnya kepada Kementrian Riset, Teknologi dan Pendidikan Tinggi Republik Indonesia atas funding yang telah diberikan dan juga UPN 'Veteran' Yogyakarta.

\section{CATATAN BELAKANG}

1 Global Witness adalah sebuah Lembaga Swadaya Masyarakat (LSM) internasional yang didirikan pada tahun 1993 yang berupaya memutus hubungan antara eksploitasi sumber daya alam, konflik, kemiskinan, korupsi, dan pelanggaran hak asasi manusia di seluruh dunia. Tujuan LSM ini adalah untuk mengekspos eksploitasi sumber daya alam dan sistem perdagangan internasional yang korup, untuk mendorong kampanye yang mengakhiri impunitas, konflik terkait sumber daya, dan pelanggaran hak asasi manusia dan lingkungan. Salah satu upaya yang dilakukan oleh organisasi ini adalah mengungkap bagaimana berlian dan sumber daya alam lainnya dapat mendanai konflik atau menjadi bahan bakar korupsi. Global Witness telah melakukan penyelidikan dan studi kasus di
Kamboja, Angola, Liberia, Kongo, Kazakhstan, Burma, Indonesia, Zimbabwe, Turkmenistan dan Pantai Gading.

2 Eurodad (European Network on Debt and Development) adalah jaringan dari 49 organisasi non-pemerintah dari 19 negara Eropa. Organisasi ini bertujuan untuk meneliti dan mengerjakan isu-isu yang terkait dengan hutang, pembiayaan pembangunan dan pengurangan kemiskinan. Target utama Eurodad adalah organisasi seperti Bank Dunia, Dana Moneter Internasional (International Monetary Fund), Organisasi untuk Kerja sama Ekonomi dan Pembangunan, juga pemerintah Eropa sendiri. Eurodad didirikan pada tahun 1990 dan terdaftar sebagai organisasi nirlaba baik di Belanda maupun Belgia. Organisasi ini didanai oleh anggotanya (sekitar sepertiga dari anggarannya) dan oleh Kementerian Luar Negeri Belanda, Badan Kerja sama Pembangunan Internasional Swedia dan Departemen Pembangunan Internasional Inggris.

3 Kerja sama sosial-budaya di perbatasan diselenggarakan misalnya oleh Dewan Adat Dayak dengan Serawak National Dayak Union dan kelompok etnis Jawa Indonesia di Malaysia seperti Pasomaja dengan YIRMI (Yayasan Ikatan Rakyat Malaysia Indonesia).

4 Kerja sama dalam bidang akademik misalnya dapat ditemukan dalam Kaboka (kajian ilmiah mengenai kawasan perbatasan), MRC (Malindo Research Centre yang didirikan oleh BNPP dan kelompok akademik Indonesia Malaysia) serta Balai Melayu (institusi independen yang menyoal budaya dan kajian akademik budaya Melayu).

5 Negara sangat minim berbagi informasi mengenai isu perbatasan, budaya dan tenaga kerja migran. Negara cenderung merespon dengan sangat lunak dan berpegang pada faktor kedekatan sejarah dan hubungan ekonomi. Beberapa kali SBY menekankan penyelesaian melalui jalur diplomatik dalam isu bilateral Indonesia-Malaysia, antara lain disampaikannya dalam pidato di Cilangkap pada tahun 2010.

6 Blog terkait misalnya http://malingsia-fuck.blogspot.co.id/; http://kamibenci-malingsia.blogspot.co.id/; http://nkrinkri.blogspot.co.id/2010/01/kumpulan-gambar-anti-malingsiayg.html, Diakses tanggal 30 Agustus 2015.

7 Media berhasil menanamkan cerita yang berbeda dengan pemerintah dalam benak publik yaitu bahwa Sipadan dan Ligitan adalah cerita mengenai 'kekalahan' Indonesia atas Malaysia. Cerita mengenai 'kehilangan' Indonesia dan cerita mengenai Malaysia yang berhasil 'mengambil' apa yang semestinya menjadi 'milik' Indonesia, seperti pada tajuk 'Pertahankan setiap jengkal wilayah NKRI yang sah!! Jangan biarkan Blok Ambalat sebagai kasus Sipadan \& Ligitan jilid 2!! menjadi satu penanda bahwa Indonesia pernah kehilangan Sipadan dan Ligitan. Lihat Kementrian Sekretariat Negara Republik Indonesia. 2002. 'Indonesia Kehilangan Pulau Sipadan-Ligitan. Tempo.Co. https://m.tempo.co/read/news/ 2002/12/17/05535037/indonesia-kehilangan-pulau-sipadanligitan. Diakses 17 Juni 2017.

8 Slogan ini dicanangkan Mahathir beberapa bulan saja semenjak ia dilantik menjadi perdana menteri tahun 1981. Slogan ini merupakan bentuk hubungan baru yang lebih dekat dengan negara-negara Asia, terutama Jepang. Secara ekonomi, 
Mahathir ingin Malaysia mengadopsi beberapa prinsip dari Jepang. Dia percaya bahwa Malaysia harus mengikuti contoh Japan Inc. dan menciptakan Malaysia Inc., di mana pemerintah dan sektor swasta bekerja sama untuk mencapai tujuan ekonomi bersama. The Look East Policy juga bertepatan dengan ambisi industrialisasi Mahathir di Malaysia. Keberhasilan Proton Saga adalah perwujudan nyata dari slogan tersebut.

9 'Malaysia Boleh!' atau yang berarti 'Malaysia Can Do It' merupakan nation branding yang dibangun Mahathir untuk menimbulkan rasa percaya diri masyarakat Malaysia yang didukung oleh sejumlah bangunan fisik seperti Petronas, KLCC, PutraJaya Cyber City.

10 Agenda for a New Asia merupakan pidato Mahathir yang diucapkan di depam Asia Society Forum di Hongkong pada tahun 2000. New Asia merupakan orientasi pembangunan yang meniru model keberhasilan pembangunan negara industrialis baru seperti Jepang, Korea Selatan, dan Taiwan serta menyoal kemandirian keuangan negara-negara Asia atas IMF.

11 Smart Partnership merupakan pernyataan Mahathir atas keberhasilan Malaysia dalam membangun kerja sama yang setara dengan berbagai pihak yang berbeda etnis, agama maupun budaya yang berhasil mendorong perekonomian Malaysia dan mampu bersaing secara global.

2 Malaysia seringkali dikaitkan oleh sebagian orang Indonesia dengan budi baik yang harus dikenang selama-lamanya karena Indonesia pernah mengirimkan ratusan guru. Sebaliknya, pemahaman mengenai 'budi baik' bagi sebagian orang Malaysia dipahami bukan karena pengiriman guru dan dosen di masa lalu melainkan 'budi baik' Malaysia yang memberikan pekerjaan pada sejumlah besar orang Indonesia. Dalam pemahaman ini maka, justru orang Indonesialah yang mestinya membalas budi baik Malaysia dengan tidak membuat 'gaduh' di negara mereka.

\section{REFERENSI}

Abd Razak, M. R., Abd, G. H., Hamzah, Z., dan Dali, A. M. 2013. 'Rekonsiliasi Hubungan Malaysia-Indonesia dalam Konteks Regionalisme Asia Tenggara'. Jebat: Malaysian Journal of History, Politics \& Strategy, Vol. 40 (1), July. pp.177-197.

Ammon, Royce. 2001. Global Television and the Shaping of World Politics: CNN, Telediplomacy and Foreign Policy. McFarland: Jefferson NC.

Azhar, Al. 2011. 'Meramaikan Negeri dengan Dagang dan Santri'. Dalam Musni Umar dan Pudentia MPSS (ed.). Membangkitkan Memori Kolektif Kesejarahan Indonesia-Malaysia. Jakarta: INSED dan EPG Indonesia.

Cast, A. D. dan Burke, P. J. 2002. 'A Theory of Self-Esteem'. Social Forces, Vol. 80, No. 3, March. Oxford University Press.

Chan, Brenda. 2005. 'Imagining the Homeland: The Internet and Diasporic Discourse of Nationalism'. Journal of Communication Inquiry October 2005 Vol. 29 no. 4 336-368.

Connelly, A. L. R. 2014. 'Indonesian Foreign Policy under President Jokowi'. Lowy Institute (daring). https://www.lowyinstitute.org/ sites/default/files/indonesian-foreign-policy-under-presidentjokowi_0_0.pdf. Diakses 30 September 2017. pp.3-4.

Covey, S. R. 1997. Tujuh Kebiasaan Manusia yang Sangat Efektif, (Terj.) Budijanto, dengan judul asli The 7 Habits of Highly Effective People. Jakarta: Bina Rupa Aksara.

de Lima Jr, Ant ô nio F. 2007. 'Students' Corner The role of International Educational Exchanges in Public Diplomacy'. Place Branding and Public Diplomacy Vol. 3, 3. Palgrave Macmillan Ltd.

Entman, R. M. 2003. 'Cascading Activation: Contesting the White House's Frame After 9/11'. Political Communication.

Eriksen, T. H. 2007 'Nationalism and the Internet'. Nations and Nationalism, Vol.13 (1).

Fukenstein, Amos. 1989. 'Collective Memory and Historical Consciousness'. History and Memory. Vol. 1 No. 1. Indiana University Press.

Gilboa, Eytan. 2002. 'The Global News Networks and US Policymaking in Defense and Foreign Affairs'. The Shorenstein Center on the Press, Politics and Public Policy. Kennedy School of Government: Cambridge.

Green, Anna. 2004. 'Individual Remembering and 'Collective Memory: Theoritical Presuppositions and Contemporary Debates. Oral History. Vol. 32 No. 2. Memory and Society.

Ham, Peter Van. 2010. Social Power in International Politics. New York: Routledge.

Hara, Abubakar Eby. Tanpa Tahun. 'Hubungan Malaysia dan Indonesia: Dari Saudara Serumpun ke 'Smart Partnership?' (daring). http://www.mahyudinalmudra.com/article/read/314/ Hubungan-Malaysia-dan-Indonesia-Dari-Saudara-Serumpun-keSmart-Partnership. Diakses 30 Juli 2017.

Jackson, R. dan Sorensen, G. 1999. Pengantar Studi Hubungan Internasional. Yogyakarta: Pustaka Pelajar.

Kansteiner, Wulf. 2001. 'Finding Meaning in Memory: A Methodological Critique of Collective Memory Studies'. History and Theoy. Vol. 41, No. 2.

Kelana, Musafir \& Hara, A. E. 2009. 'Quo-vadis Kekerabatan Malaysia-Indonesia?' Jurnal Komunikasi Massa - Vol. 2 No. 2 Januari 2009.

Kenchappanavar, N. 2012. 'Relationship between Inferiority complex and Frustration in Adolescents'. IOSR Journal of Humanities and Social Science (JHSS) ISSN: 2279-0837, ISBN: 2279-0845. Volume 2, Issue 2 (Sep-Okt), pp. 01-05.

Kernis, M. H. 2003. 'Toward a Conceptualization of Optimal SelfEsteem'.Psychological Inquiry, Vol. 14, No. 1. Taylor \& Francis, Ltd.

Kupinska, Karolina. 2010. Contemporary Multitrack Diplomacy Across the Taiwan Strait. Thesis on Ming Chuan University. Taiwan.

Leonard, M., Stead, C., and Sweming, C. 2002. Public Diplomacy, The Foreign Policy Centre: London (daring). http:// www.fpc.org.uk. Diakses April 2013.

McGeer, Victoria. 2010. 'Co-reactive Attitudes and The Making of Moral Community' (daring). http://www. princeton.edu/ 〜vmcgeer/papers/McGeer2010CoreactiveMS.pdf. Diakses 30 September 2017.

Maksum, A. dan Bustami, R. 2014. 'Ketegangan Hubungan 
Indonesia-Malaysia dalam Isu Tarian Pendet.'. Kajian Malaysia, Vol. 32, No. 2, pp. 41-72. Penerbit Universiti Sains Malaysia.

McDowell, Mark. 2008. 'Public Diplomacy at the Crossroads: Definitions and Challenges in an 'Open Source' Era'. The Flethcher Forum of World Affairs. Vol. 32:2 Special Edition.

Malik, Sajjad. 2012. 'Track II Diplomacy and Its Impact on Pakistan India Peace Process.' Studies, Institute of Strategic Studies Islamabad (ISSI) XXXII, no. 1 (Spring).

Malau, I. L. F. dan Priatmojo, D. 2011. 'Penjelasan Kodam Tanjung Soal Camar Bulan' (daring). http://nasional.news.viva.co.id/ news/read/253928-tni-camar-bulan-masuk-wilayah-malaysia. Diakses 6 Juni 2016

Nasir, Zulhasril. 2011. 'Indonesia-Malaysia: Kesamaan Sejarah, Tradisi Budaya dan Bahasa'. Dalam Musni Umar dan Pudentia MPSS Membangkitkan Memori Kolektif Kesejarahan IndonesiaMalaysia. Jakarta: INSED dan EPG Indonesia.

Luhmann, Niklas. 1995. Social System. California: Stanford University Press.

Pertiwi, S. B. 2014. The Rise of Territorial Dispute and the Stability of Southeast Asia. Tesis. Faculty of the School of the International Service. Washington DC: American University (daring). http://islandora.wrlc.org/islandora/object/ thesesdissertations\%3A322/datastream/PDF/view. Diakses 7 Juni 2016.

Piccone, T. dan Yusman, B. 2014. 'Indonesian Foreign Policy: 'A Million Friends and Zero Enemies'. The Diplomat (daring). https://thediplomat.com/2014/02/indonesian-foreign-policy-amillion-friends-and-zero-enemies/. Diakses 1 Oktober 2017.

Polleta, F. dan Jasper, J. M. 2001. 'Collective Identity and Social Movement'. Annual Review of Sociology. Vol. 27.

Postmes, T. dan Brunsting, S. 2002. 'Collective Action in the Age of the Internet.' Mass Communication and Online Mobilization. Social Science Computer Review, Vol. 20 No. 3, Fall 2002.

Pretorious, Rina-Louise. 2011. Polylateralism as Diplomatic Method. The Case of Kimberley Process 2000-2002. University of Pretoria.

Pudentia MPSS. 2011. 'Budaya sebagai Perekat Hubungan Indonesia-Malaysia'. Dalam Musni Umar dan Pudentia MPSS Membangkitkan Memori Kolektif Kesejarahan IndonesiaMalaysia. Jakarta: INSED dan EPG Indonesia.

Rachmawati, Iva. 2017.' Indonesian Public Diplomacy: Preserving State Existence through Sharing of Indetities to Gain Mutual Understanding'. Jurnal Global \& Strategis

Vol 1, No 11: Jurnal Global \& Strategis 11.1 201. pp. 55-71.

Scanlon, T. M. 2008. Moral Dimensions: Permissibility, Meaning, Blame. Cambridge, MA: Harvard University Press.

Sharp, Paul. 2001. 'Making Sense of Citizen Diplomats: The People of Duluth Minnesota, as International Actors'. International Studies Perspectives, Vol. 2, pp. 131-150.

Supanggah, Rahayu. 2011. 'Kesenian Media Persaudaraan Antar Bangsa'. Dalam Musni Umar dan Pudentia MPSS ed. Membangkitkan Memori Kolektif Kesejarahan IndonesiaMalaysia. Jakarta: INSED dan EPG Indonesia.

Suwirta, Andi. 2010. 'Dua Negara-Bangsa Melihat Masa lalunya: Konfrontasi Indonesia Malaysia (1963-1966) sebagaimana Dikisahkan dalam Buku-Buku Teks Sejarahnya di Sekolah'. Jurnal
Sosiohumanika. 3 (2).

Wirajuda, Muhammad Hadianto. 2014. The Impact of Democratisation on Indonesia's Foreign Policy: Regional Cooperation, Promotion of Political Values, and Conflict Management. Disertasi. The Department of International Relations of The London School of Economics and Political Science.

Zaharna, R. S. 2009. 'Mapping Out a Spectrum of Public Diplomacy Initiatives'. Dalam Nancy Snow ed. Routledge Handbook of Public Diplomacy. Routledge: New York.

Zakiah, Kiki. 2012, 'Pencitraan Indonesia di Media Massa Malaysia'. Jurnal IImu Komunikasi, Vol. 2, No.1, April.

Zakiah, Kiki dan Dede Fardiah. 2012. 'Potret Indonesia di Media Massa Malaysia'. Prosiding Seminar Nasional Penelitian dan PKM: Sosial, Ekonomi dan Humaniora 2012.

ILMIA-Ministry of Human Resources of Malaysia. 2013. Immigration in Malaysia: Assessment of its Economic Effects, and a Review of the Policy and System. Human Development Social Protection and Labor Unit East Asia and Pasific Region. World Bank.

Kementerian Sekretariat Negara Republik Indonesia. 2009. 'Sambutan Presiden RI pada Asian Parliamentary Assembly, Bandung-Jabar, 8 Desember (daring). http://www.setneg.go.id/ index.php? option $=$ com_content\&task $=$ view\&id $=4224$. Diakses 3 Juni 2016.

2002. 'Indonesia Kehilangan Pulau Sipadan-Ligitan'. Tempo.Co (daring). https://m.tempo.co/read/news/2002/12/17/ 05535037/indonesia-kehilangan-pulau-sipadan-ligitan. Diakses 17 Juni 2017.

2010. 'Isi Lengkap Pidato SBY Soal Malaysia'. Detik News (daring). http://news. detik.com/berita/1433134/isilengkap-pidato-sby-soal-malaysia. Diakses 2 Juni 2016. Tanpa Tahun. 'Seruan Soekarno: Hajar Cecunguk Malayan, Ganyang Malaysia!' (daring). https:// www.intelijen.co.id/seruan-soekarno-hajar-cecunguk-malayanganyang-malaysia/. Diakses tanggal 5 Mei 2016.

Wawancara dengan Musni Umar di Jakarta, tanggal 26 April 2015

Wawancara dengan Mahyudin Al Mudra di Yogyakarta, tanggal 30 Juni 2015.

Wawancara dengan Tohakim di Kulim, tanggal 16 September 2015.

Wawancara dengan Adian Napitupulu di Jakarta, tanggal 26 April 2015. 